\title{
Разрушение тканевых композитов с концентраторами напряжений: учёт неупругого деформирования в численном моделировании
}

\section{Failure of fabric reinforced composite with concentrators: implementation of inelastic deformation in numerical simulation}

\section{С. Б. Сапожников}

Южно-Уральский государственный университет,

Челябинск, Россия

Поступила в редакцию14.07.2020, принята к печати 21.07.2020

\author{
S. B. Sapozhnikov \\ South Ural State University, \\ Chelyabinsk, Russia
}

\begin{abstract}
Абстракт
В данной работе на основе расчётно-экспериментального исследования механических свойств слоистого тканевого стеклопластика показано, что нелинейные диаграммы «напряжение-деформация» при растяжении вплоть до разрушения вдоль основы/ утка возможно численно моделировать, рассматривая его как совокупность двух специальных субслоёв - нитевого и матричного. Использован МКЭ-пакет ANSYS Workbench с явной схемой интегрирования и технологией удаления разрушенных конечных элементов. Нитяной субслой моделируется упругой ортотропной средой с нулевым модулем сдвига, тогда как модель матричного субслоя - изотропное идеально упругопластическое тело. Разрушение субслоёв по всем механизмам независимое, критерии разрушения деформационные. Для тонкостенных конструкций показана возможность корректного предсказания нагрузки разрушения в присутствии концентраторов напряжений типа отверстия и острого надреза с использованием МКЭ и теории критических расстояний с размером конечного элемента 1 мм.
\end{abstract}

\begin{abstract}
A computer simulation and experimental study of the mechanical properties of laminated glass fibre reinforced plastics shown that nonlinear tensile stress/strain diagrams up to failure can be modeled considering the material as a combination of two specific sublayers, those being the filament and matrix. The FEM package ANSYS Workbench with an explicit integration scheme and a possibility to remove finite elements after their failure was used. The filamentous sublayer is modeled by an elastic orthotropic medium with zero shear modulus, while the matrix sublayer model is modeled by an isotropic ideal elastoplastic body. The failure of the sublayers is mutually independent; reaching ultimate strains failure is accepting as the failure criteria. For thin-walled structures, the possibility of correct prediction of the failure load in the presence of stress concentrators such as a hole or sharp notch using the FEM and the theory of critical distances with a finite element size of $1 \mathrm{~mm}$ is shown.
\end{abstract}

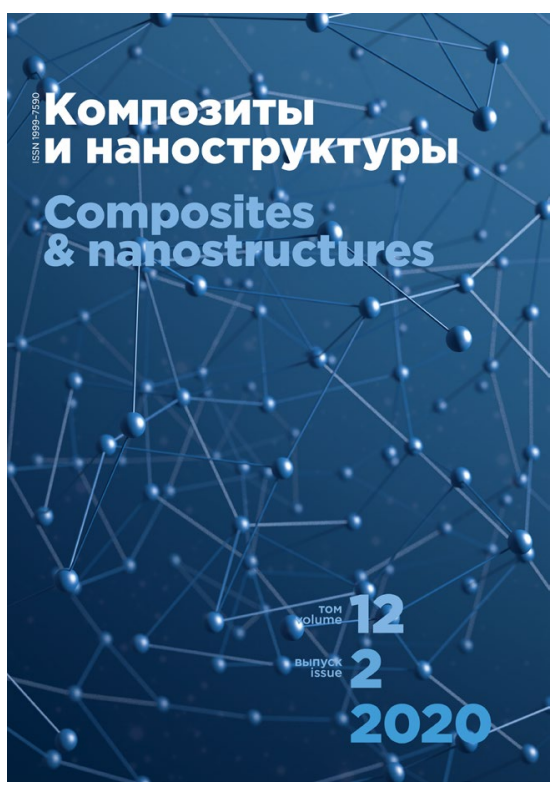

